\title{
OPPORTUNITIES FOR QUALITY ASSURANCE IN TOURISM BUSINESS
}

\author{
L. Ilieva* \\ Department of Tourism Economics and Management, D. A. Tsenov Academy of Economics - \\ Svishtov, Bulgaria
}

\begin{abstract}
In order to achieve long-term national priorities - competitiveness and sustainable growth, tourism businesses need to realize the economic relevance of quality management. The study of this problem and its application in tourism practice is particularly relevant given current state and industry initiatives, regulatory and voluntary quality assurance tools. As the quality of the tourist product is a collection of many elements, including the development of modern and developed infrastructure at local and state level; professional training of staff employed in the sector; ensuring security of residence; ensuring a clean environment; the provision of safe services, etc., the main objective of the present study is to research and elucidation the possibilities for quality assurance in Bulgarian tourism enterprises. To achieve this, it is necessary to carry out a theoretical analysis and practical study of the tools used to ensure the quality of the tourist business. As a result of the research, the main normative and voluntary instruments for quality assurance and control in the tourist business are examined, the attitude of the tourism business and the consumers towards the voluntary certification of Quality Management Systems and offered effective measures proposed to promote the initiative of the Bulgarian business to quality assurance of the services offered.
\end{abstract}

Key words: quality, quality management systems, ISO 9001, tourism business

\section{INTRODUCTION}

A decisive factor for the development of national tourism is the availability of sustainable and competitive tourism enterprises operating in line with current world trends. Quality assurance depends on excellence in two areas - design of goods and services and quality control during service delivery, supported by some form of control and inspection (1).

Most authors unite around the views of $\mathrm{C}$. Groenroos and E. Schaetzing (2) on quality by considering it in two aspects - technical (hardware of the "Quality service system" Hardware - Qualitaet) and functional (software of the "Quality service system" - Software Qualitaet, Gast - Beziehungs - Qualitaet).

- the first refers to the resulting final result, i. the quality of the service received or the

\footnotetext{
*Correspondence to: Lyubka Mincheva Ilieva, Department of Tourism Economics and Management, D. A. Tsenov Academy of Economics - Svishtov, +359896824343, e-mail: l.ilieva@unisvishtov.bg
}

technical quality. To the technical aspect of quality are the characteristics: reliability of service, accuracy, speed, operability and expertise (competence).

- the second one contacted the way the service was provided, ie. the quality of the service process or the functional quality. The functional aspect of quality includes: the attitude of staff towards customers, appearance, atmosphere, responsiveness, empathy.

Both aspects of quality actually express the quality of tourism services, which has two dimensions (3): objective quality - it is expressed in real characteristics product and subjectively (perceived) quality - it is expressed in the comparison between customer pre-expectation and service delivery in the service process.

The provision of tourist services in a way that is perceived by tourists as qualities is a major goal not only for the business but also for the state, which is the body for managing, regulating and controlling tourist activities, services and sites. To ensure objective quality 
should respect fundamental requirements to the material elements of the tourism product, which is enshrined in the legislation, such as through the system of categorization of tourist facilities, but to be ensure consumer satisfaction, the subjectively perceived quality of the tourist product should be ensured by taking into account consumer expectations for this type of tourist product.

The main objective of the present study is to explore and outline the possibilities for quality assurance in the Bulgarian tourism enterprises. To achieve this, it is necessary to carry out a theoretical analysis and a practical study of the tools used for quality assurance from the tourist business. As a result of the research are being show the basic regulatory and voluntary tools to ensure quality control in tourism, are being survey the attitude of the tourism business and consumers to voluntary certification systems for quality management and propose effective measures to encourage the initiative of Bulgarian business for quality assurance of the services.

\section{Quality Assurance arrangements in Tourism}

The provision of a quality tourist product and service is mainly related to the primary tourism sector and therefore the requirements for tourist sites where the provision of basic tourism services is provided are often subject to control by international, national and branch organizations through their inherent arrangements.

Typical are systems of classification ${ }^{1}$, they are widely used in the accommodation sector as a means of indicating the level of facilities, equipment, furnishings and the variety of services provided in tourist sites to both consumers and intermediaries.

In the Bulgarian system of classification (categorization) of tourist sites are laid down the quantitative standards which represent the minimum state requirements for the construction, furnishing and equipment of the tourist sites, the services and the offered services in the tourist site, education or

\footnotetext{
${ }^{1}$ Hotel classification is the ranking of hotels, usually by using a nomenclature such as stars (or diamonds), with one star indicating the basic amenities and comfort requirements, while five stars denote luxury in the facilities and services. The goal is to inform future guests in advance of what can be expected, to reduce the difference between expected and actually received amenities and services. The terms "ranking", "rating", "classification" and "category" are used to refer to the same concept, ie. for ranking hotels on their facilities and service.
}

ILIEVA L.

professional qualification, traineeship in the tourism and language qualification of the manager, professional and linguistic qualification of the staff of the tourist site. This is mainly related to the technical characteristics of the quality on which the tourism company can have an impact, covering the requirements for the conditions and the services it provides, with the role of the state being to control their quality.

According to the requirements of national regulations, classification systems may be mandatory and voluntary. In Bulgaria, according to the current Tourism Act and the Ordinance on the Requirements for the Accommodation and Catering and Entertainment Facilities and the Procedure for Categorization, Refusal, Decrease, Suspension and Termination of the Category, a mandatory categorization is adopted for all sites, in which tourism services are provided, and assure in fact the quality of the material base in tourism, and hence the tourist services for which it provides the conditions to be provided. This is logical as the development of the tourism business influences the local community and should state commitment to quality assurance in tourism services through regulation of tourism and the categorization and certification systems of tourist sites.

The role of the state is not limited to defining the requirements and the control over the material base and the scope of services of the tourism enterprises, but it also develops in the direction of stimulating enterprises to selfinitiative in order to improve them the quality. This is through various measures that initiate the Ministry of Tourism, scientific and branch organizations.

The project "Stimulating the Quality and Sustainable Development of Tourism Enterprises", developed by the Ministry of Economy, Energy and Tourism in 2008-2012, for researching the attitudes of tourism business to certification of quality systems and sustainable development and report a strong interest in issues related to the quality assurance of the products offered. The results obtained are the basis for planned measures for quality assurance in tourism in the 2014-2030 National Strategy for Sustainable Tourism Development in the Republic of Bulgaria (4), concrete actions are planned in the Action Plan for the period 2017-2020 for its implementation (5) and which are also laid 
down in the Draft Law on Amendments to the Tourism Act (18.05.2018) (6). By the end of 2020 , it is planned to introduce a National Quality Certification System for Tourism (or national quality label), which a voluntary "Quality Label" to be awarded to hotels and establishments that meet additional statutory requirements, according to a Regulation issued by the Ministry of Tourism. In this way, it is planned to stimulate the owners, who make additional efforts to increase the quality of their products, and to help consumers in the search for a quality product on the tourist market.

Tourism companies, which perceive the quality of their product and service as a priority, choose the way of voluntary certification under national and global standards, awards, markings and labels. As Bozhinova points out (7), "in the modern economy there are cardinal changes in the relations between market participants, with the role of consumers increasing," which requires organizations to look for solutions to distinguish it from other market participants. They allow for differentiation between tourist sites offering identical tourist products in one destination, creating a brand and building a positive image through worldwide recognizable markings and quality signs.

In Bulgaria, among the tourism business, there are very few worldwide and European quality signs such as:

\section{EDEN (European Destinations of}

Excellence) - an initiative of the European Commission that promotes and publicize sustainable tourism development models throughout the European Union. As Georgieva points (8) out the tourist destinations with their multitude and variety today are forced, to differ from one another to continue to be attractive to tourists on the one hand and to generate income and jobs on the other. The prized Bulgarian destinations from the beginning of the initiative until now are 17 in number.

PAN Parks certificates are a sign that the protected area is protected due to the importance of biodiversity in it and its role for the development of society through sustainable tourism. In Bulgaria are certified with this sign - Central Balkan Park and Rila Park.

Blue flag - an eco-label that is recognizable throughout the world. The Blue Flag program
ILIEVA L. Environmental Education Foundation and is based in Copenhagen, Denmark. Prizes for 2018 received 13 beaches and 1 marina in Bulgaria.

Green Key - The Green Key Award is the leading standard of excellence in the field of environmental responsibility and sustainable business in the tourism industry. This prestigious eco-label represents the commitment of the business that their premises meet the strict criteria set by the Environmental Education Foundation. There are 2553 certified sites in 26 countries in Europe, but only 2 certified tourism enterprises in Bulgaria (9).

Travelife - a web-based certification system that allows accommodation providers to monitor and self-assess their sustainability, after that auditors assess their compliance with the criteria of the standard. The program follows a three-tier approach: Stage 1: Travelife Engaged - at this stage, the company has not yet been rewarded; Stage 2: Travelife Partner - based on a report on sustainability and compliance with the key requirements assessed by Travelife, the company has reached the status of Travelife's partner. With such a sign in Bulgaria there are 9 tourist enterprises; Stage 3: Travelife Certified - The company's compliance with the International Certification Standard for Travel Organizations is assessed by an independent auditor and follows Certificate of Compliance with a "Travelife Certified" Certificate. In Bulgaria only 1 tourist enterprise is with this certificate (10).

Wider popularity in Bulgaria, there are nationally-recognized standards and markings that combine the green and sustainable development of tourist businesses and destinations with the specifics of the tourist product:

Authentic Bulgaria - an independent brand for quality in tourism, launched in June 2006 with the support of US Agency USAID. Awarded in support of quality and original tourist product based on several core values service professionalism and true Bulgarian hospitality, impeccable quality of service, responsible attitude to the environment and constant striving to improve the working environment. According to the Authentic Bulgaria website (authenticbulgaria.org), whit this mark has been awarded 11 organizations. 
Green Lodge ${ }^{\circledR}$ has been in operation since 2008 and has, unfortunately, lost its popularity over the years. It has been developed to award tourist sites providing services to the accommodation, distinguished by an authentic welcome and care for nature in serving its guests (guesthouses and family hotels). According to data from the BAAT website (www.baatbg.org), Green Houses in Bulgaria are 8.

It can be summarized from the presented marks and certificates that they generally cover the sustainable management of tourist sites and destinations but show the profiling of tourist sites in the offered services - mainly related to ecological and sustainable tourism. These marks and standards don't ensure the quality of the tourist product, although the process for certification, marking and labeling system is to confirm, on the one fulfill, the ability of the tourist enterprise to meet the criteria and principles set out therein and, on the other hand, gives the opportunity companies to distinguish themselves from their competitors by controlling, maintaining and optimizing their operations and service, which ultimately leads to an improvement in the overall quality of the offer their products and services tailored to the requirements and expectations of customers and the community.

In this regard, organizations often choose to be certified by internationally recognized management systems standards that enable tourism businesses to follow good practices and manage their internal and external processes to offer and guarantee a quality end result.

Food Safety System HACCP - abbreviation of Hazard Analysis and Critical Control Point. Critical control points are managed in order to keep the level of danger, reduce or eliminate it According to the Bulgarian Enterprise Information System (11), 28 are certified enterprises in the "Hotels and restaurants" sector.

ISO 14001 "Environmental Management Systems" - sets environmental management system requirements that can be integrated with other management requirements to help the organization achieve both economic and environmental goals environment. According to the Bulgarian Enterprise Information System (11) there are 8 certified enterprises from the "Hotels and restaurants" sector.

ISO 22000 "Food Safety Management Systems" - defines the requirements of the food safety management system in the food chain when an organization has to demonstrate its ability to control food dangers to ensure that each
ILIEVA L.

food product is safe to the person at the time of consumption. According to the Bulgarian Enterprise Information System (11), with ISO 22000 certificates are 18 enterprises in the "Hotels and Restaurants" sector.

ISO 9001 "Quality Management System" - a certification standard that gives entrepreneurs additional confidence that they have not only achieved the required quality in their business but also that an independent party - the quality certification body has checked this. According to the Bulgarian Enterprise Information System (11) there are 56 certified enterprises from the "Hotels and restaurants" sector.

From the presented standards and systems for management and quality assurance in the tourism business and the number of certified tourist sites and enterprises, it is evident that the certification of the tourism business according to ISO 9001 is the most widely distributed.

\section{Survey of the representatives of the tourist business and the customers to the ISO 9001 certification}

Between November 2018 and February 2019, a survey was conducted to send questionnaires to representatives of the tourism business and consumers to explore their attitude towards quality and certification ${ }^{2}$. Both questionnaires were asked the same question (Figure 1 and Figure 2). "Do you think that the categorization of accommodation and dining and leisure facilities is sufficient to guarantee the quality of tourist services?"

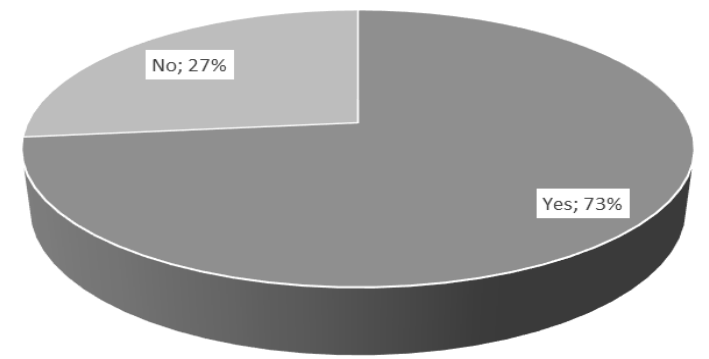

Figure 1. Evaluation of the compliance of the categorization with the quality of the tourist services provided by the business

\footnotetext{
${ }^{2}$ Polls were dispatched to 760 tourist enterprises carrying out tourism activities, of which only 30 were returned. Notwithstanding the small number of answers received, the results make it possible to take into account the opinion of entrepreneurs who have a position on the issues studied. In parallel with the research of the representatives of the tourist business, are research and the opinion of 110 customers regarding the certification of the tourist enterprises and its relation with the quality of the services they offer.
} 


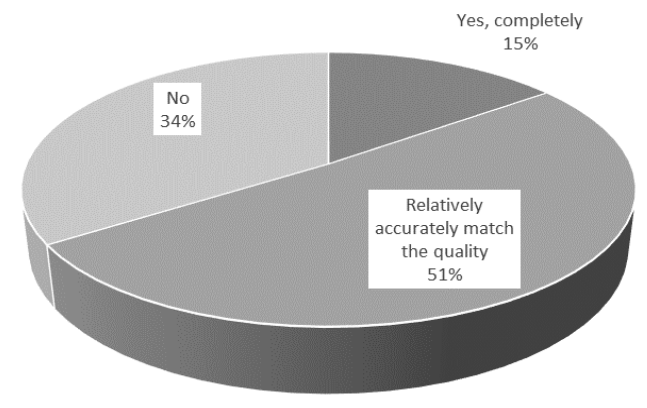

Figure 2. Evaluation of the compliance of the categorization with the quality of the tourist services provided to the customers

As can be seen from Figure 1, 73\% of the tourist enterprises surveyed responded positively, the remaining $27 \%$ do not consider it sufficient, whereas, as shown in Figure 2, $15 \%$ of the respondents answered positively and $51 \%$ responded that they were fairly accurate to their quality, 34\% said they did not match. The users are asked a supplementary
ILIEVA L.

question: "Do you consider that the license of tour operators and agents is sufficient to guarantee the quality of their services?", Of which 38\% responded positively, while 64\% said it was not enough.

This discrepancy in business opinion and consumer hesitation about the relationship between the category and the quality of the services, offered reveals a dissonance between the expectations of consumers and the views of the business for the scope of services, which could lead to dissatisfaction and poor assessment of the quality of tourism services.

On the question to the representatives of the tourism business, do they intend to be certified to improve the quality of their services, they responded ambiguous (Figure 3).

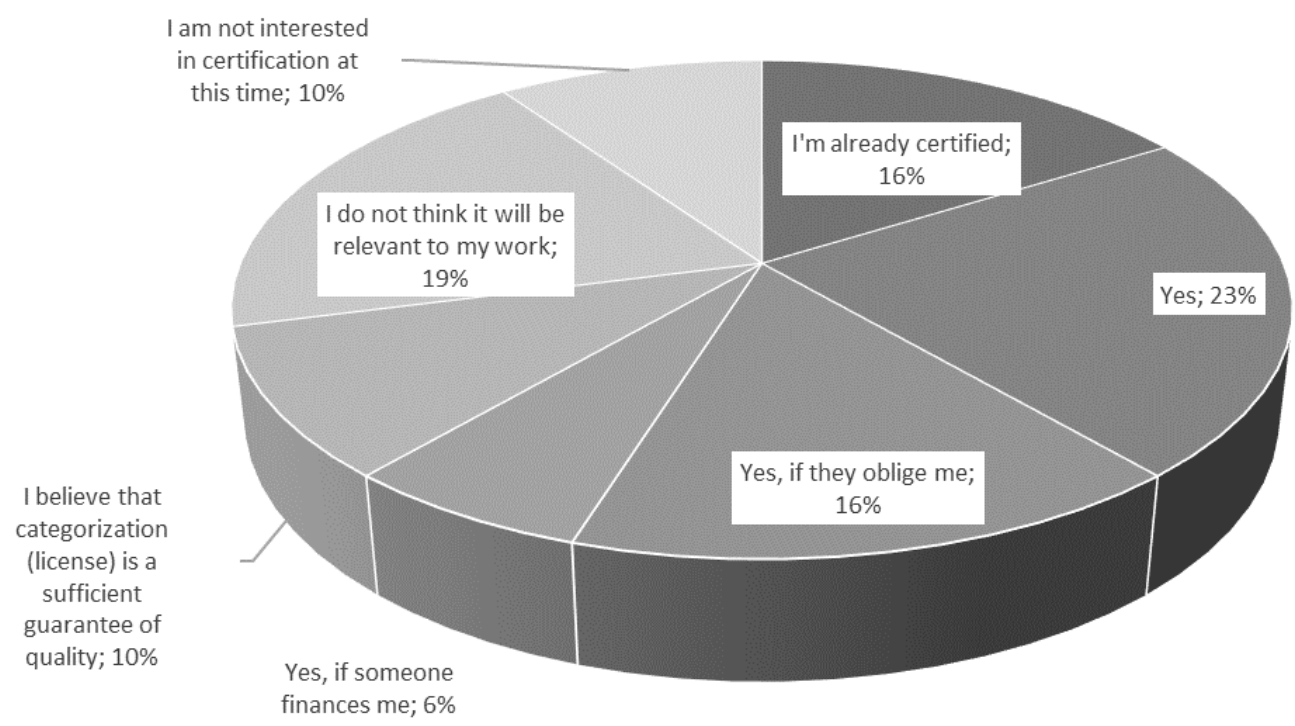

Figure 3. Assessment of the willingness of the business for certification to improve the quality of tourism services

$16 \%$ of the respondents are already certified, while $45 \%$ of the uncertified ones would be certified, whether voluntarily (23\%), obligated $(16 \%)$ or funded by someone $(6 \%)$. The remaining $19 \%$ of respondents do not consider it appropriate to take steps towards certification. The results show the readiness of almost half of respondents to take this step as an opportunity to ensure their quality of service.
Only $17 \%$ of the surveyed tourism enterprises are ISO 9001 certified, the remaining $83 \%$ are not, which provokes the study of their interest for certification to ISO 9001. The answers about this issue are again varied, as can be seen from Figure 4, but the prevails the negative attitude $-60 \%$ prevails. 


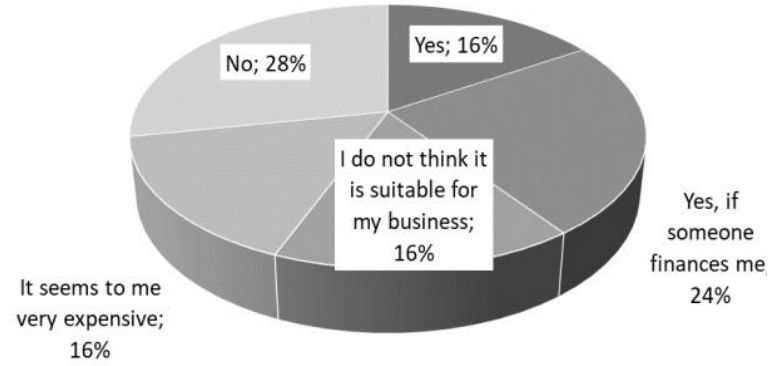

Figure 4. Examining the readiness of the business to ISO 9001 certification

From the respondents' answers, $40 \%$ of the tourist enterprises are ready to move to certification, of which $24 \%$ prefer someone else to fund the procedure, which corresponds to the responses to $16 \%$ of respondents who estimate that the certification is expensive for them. The data show a strong uncertainty about the applicability of the standard in the tourism business for $16 \%$ of respondents. $28 \%$ responded negatively concerning their readiness to move to certification.

On the question "Do you think the ISO 9001 certification is right for your business?", $38 \%$ answered positively and ditto negatively, which shows business fluctuations about the benefits of the standard. This is also evidenced by the percentage of respondents that they cannot they judge (24\%).

On the other hand, consumers are more likely to believe that the certification of the business will have a positive impact on the quality of the services offered (Figure 5)

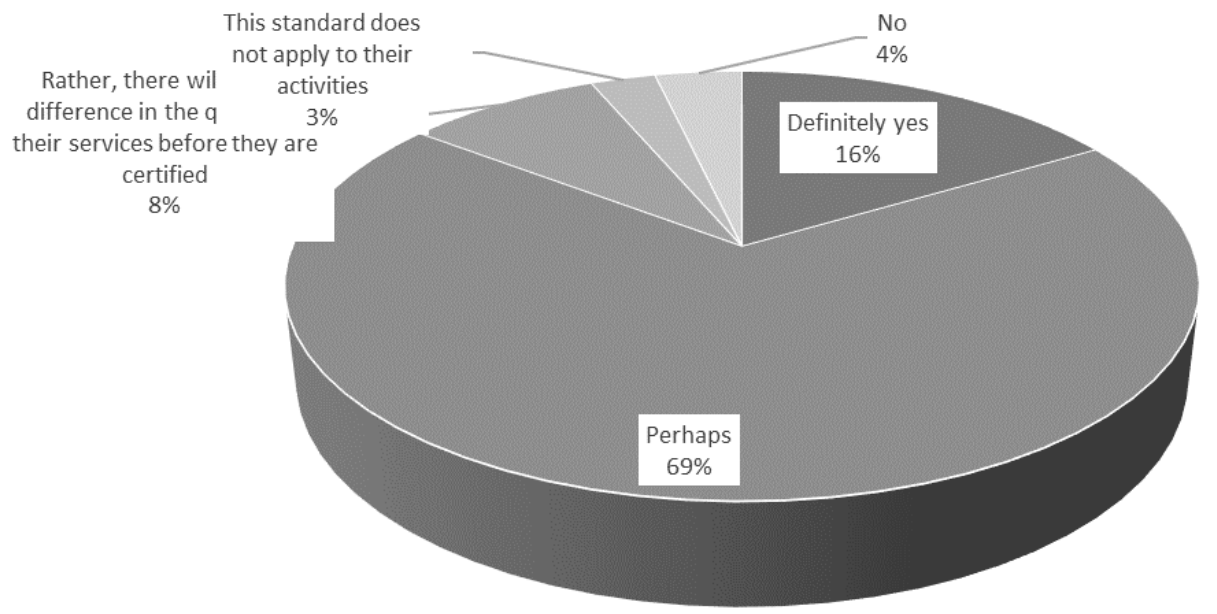

Figure 5. User rating to what extent ISO 9001 certification will effect on the quality of tourism services

As can be seen from the figure, $16 \%$ of respondents are confident that if the tourist establishment is ISO 9001 certified, the quality of their services will be higher, $69 \%$ consider that the certification for in all likelihood will positively affect quality, while $12 \%$ think there will be no difference, and 3\% do not associate the standard with tourism services.

Adopting the standard as a real opportunity for tourist business can be seen from the answers to the question, would they be certified according to ISO 9001 if they are present the concrete benefits of doing so. 92\% of respondents definitely would be certified and only $8 \%$ would not.
The data give reason to invest in promoting the standard both among business and consumers as a worldwide recognized standard having its place in the tourist industry as a means of improving the quality of services offered by Bulgarian tourism enterprises.

The weak interest of the Bulgarian tourism business in the certification and marking of their tourist sites was demonstrated by the presentation of popular signs and quality marks in European and world practice. However, users consider (Figure 6) that certification of tourism business would have a positive impact on it and its image, quality of service and consumer confidence. 


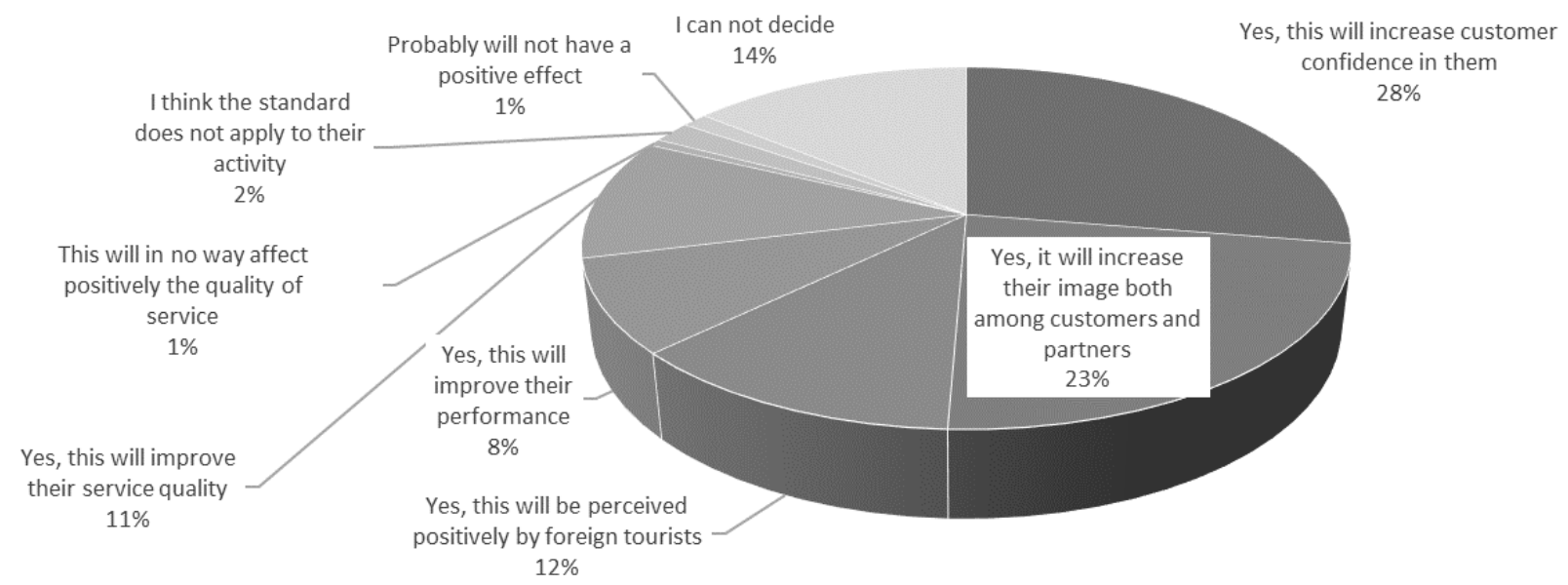

Figure 6. Customer Assessment of the Benefits of Certification by ISO 9001

As can be seen from the figure, $82 \%$ believe that certification would have a more positive impact on the business.

Asked, are they familiar with the plans that the Ministry of Tourism has put into place for the implementation of a national quality certification system (or national "Quality Label") in tourism by the end of 2020 , only $24 \%$ of enterprises and users are responded positively. The remaining $73 \%$ are unaware. $67 \%$ of the business to support them, $24 \%$ do not support them, and $14 \%$ respond that they do not know them to support them and need information. Almost the same percentage of consumers support the planned measures of the ministry $-62 \%$, while only $38 \%$ do not support them. This justifies recommending the continuation of the planned by the state and the branch organizations activities related to the promotion of the business in order to increase the quality of the offered products and services and dynamizing the information events concerning the criteria and benefits of the voluntary certification.

The answers to the last question prove that the issue of quality in tourism is a hot topic for both state authorities and business. The Ministry's plans to build a voluntary certification system are clearly not justified by businesses that do not see the real benefits of it. This could make it difficult to implement it. But the fact that businesses and consumers are familiar with ISO 9001, gives reason to suggested certification by the standard to be linked to receiving the quality label of the Ministry of Tourism.

\section{CONCLUSION}

On the basis of this study, the following recommendations can be outlined for undertaking specific measures for the wider introduction of ISO 9001 in the tourism business in order to increase the quality of the Bulgarian tourist product and the easy entry of the voluntary certificate "Quality label" of the Ministry of Tourism:

Firstly, it is expedient to coordinate and adapt to each other all policies related to quality in individual tourism activities, of state, nongovernmental organizations and industry associations. This measure would increase the impact of current and future initiatives and efforts to promote the competitiveness and quality of Bulgarian tourism product.

Secondly, it is necessary to give publicity to the planned actions of the state, and in particular on the Ministry of Tourism, on the introduction of the voluntary certification system, as businesses and consumers should know before they are offered the application of this system. The reported ease of application of ISO 9001 and its recognition as a quality sign is a reason to consider promoting the application of this standard by tourism enterprises and its acceptance as a condition for awarding the quality label prepared by the Ministry of Tourism.

Thirdly, the survey results take into account barriers to ISO 9001 certification linked to the high cost of maintaining it, which requires a policy to promote the importance of certification for customers and tourism organizations, focusing on the economic effects it brings certification and returns from investments in it. Another appropriate measure for business promotion is the partial funding of the initial certification, as required sustainability in its maintenance.

Fourthly, it is appropriate that the planned changes in the Tourism Act, on quality management in tourism, should comply with 
the principle of separation of powers laid down in the conceptual framework of the law and avoid the possibility for the regulating body to certify and control itself. It is necessary to promote the activities of certification organizations as they are part of a working mechanism for assessing the adequacy of quality management systems and are an objective and independent body. They could carry out the planned certification activities by the Ministry of Tourism, which is yet to build new certification structures on the voluntary quality label.

Fifth, it is advisable to create a single register of certified enterprises at the Bulgarian Institute for Standardization. This will assist users and control authorities in making inquiries and checking for the up-to-date information. The Draft Law on Amendment and Supplement to the Tourism Act provides for the authority that summarizes the information on the "Quality Label" certified sites to be the Ministry of Tourism. It is appropriate to create a Register of ISO 9001 certified enterprises in tourism, or at least to indicate their certification according to the standard in the information on tourist sites in the current registers. This would make it easier for contractors and customers who prefer to work with organizations with proven quality management systems or that require such certification from their travel service providers. Some of the presented standards are aimed at generating quality, laying down certain norms and requirements for the material base of the tourist sites and the way of providing the services. They mainly serve as a classification and categorization of tourist sites. Other standards set their requirements to preserve the environment in which implement tourism is being pursued and aim to classify businesses as sustainable and environmentally friendly. The third is focused on quality management by identifying, monitoring, analyzing and improving the processes occurring in the organization by building a management system to ensure a quality end product tailored to the requirements of the tourists. Due to the fact that the majority of similar quality management schemes created specifically for
ILIEVA L.

the tourism sector are based almost entirely on the international ISO 9001 standard, is reason to take measures to promote ISO 9001 certification as an opportunity not only for guarantee of the quality of the tourist product but also for effective management of the activity of the tourist enterprise by observing the principles of the standard.

\section{REFERENCES}

1. Jennings, G. R. (2006). Quality tourism experiences - An introduction. In Quality tourism experiences, 1-21.

2. Neshkov, M., Dabeva, Т. и кол. (2003). Kachestvoto na balgarskia turisam - mit $i$ realnost. Varna: Slavena. c. 92

3. Lukanova, G. (2017). Socialnoikonomicheski izmerenia na hotelierskoto obslujvane. Varna: Nauka i ikonomika, c. 93

4. Marinov, S. i kol. (2014). Nacionalna strategia za ustoichivo razvitie na turisma $\mathrm{v}$ Republika 2014-2030 g. Sofia: Ministerstvo na turisma.

5. Plan za deistvie za perioda 2017-2020 g. Kam Aktualiziranata Nacionalna strategia za ustoichivo razvitie na turisma $\mathrm{v}$ Republika 2014-2030 g., $\quad 02.02 .2018$ (Reshenie №65/02.02.18г.).

6. Zakon za izmenenie I dopalnenie na Zakona za turisma, Obn. DV, br.30 ot 2013г (izm. i dop. DV, br. 37 ot 2018 g.).

7. Bozhinova, M. (Volume 13 Issue 10 Version 1.0 Year 2013). Private Label Retailers' Competitive Strategy. Global Journals of Management and Business Research Marketing, 28-34. p.29

8. Bozhinova, M., Pavlov, P., Todorova, L., Valkova, V. (Том 25, 2018, chast II). Sastoyanie, problem I perspektivi pred predpriemachestvoto $\mathrm{v}$ sferata na turisma $\mathrm{v}$ Balgaria. Almanah nauchni izsledvania, 104-135. c. 15

9. www.greenkey.global

10. www.travelife.info

11.BEIS. (май 2018 r.). Sertificirani firmi. Izvlecheno ot Informazionna Sistema za balgarskite predpriyatia: http://beis.biabg.com/index.php?p=isolist 